Journal of Teacher Education for Sustainability

vol. 11, no. 1, pp. 31-42, 2009

\title{
DEVELOPING THE MODEL ON THE LEARNING FOR SUSTAINABLE DEVELOPMENT IN HIGHER EDUCATION
}

\author{
Liisa Rohweder \\ Haaga-Helia University of Applied Sciences, Finland \\ Anne Virtanen \\ Hamk University of Applied Sciences, Finland
}

\begin{abstract}
The study highlights how higher education institutions could be proactive leaders in promoting societal change for sustainable development. In total, 30 researchers and teachers of Education for Sustainable Development (ESD) from universities in the Baltic Sea Region participated in the development of a model on learning for sustainable development by introducing educational cases and developing the important factors of ESD, based on these cases, their own experience and theoretical knowledge. The critical factors of ESD were re-developed and categorised into contextual (integrative approach, time perspective and spatiality), mental (value clarification, systemic thinking, critical reflection and motivation building) and activity (partnership, cooperation, communication and participation) related aspects. By using these critical factors in higher education, teachers can more likely ensure that the outcome of the learning process will increase competences for sustainability. The development of the model was based on a constructive research approach rarely used in pedagogical research. Therefore, the study increased the understanding of participants about this qualitative research tradition.
\end{abstract}

Key words: Education for Sustainable Development; higher education; constructive approach; Baltic Sea Region.

\section{Introduction}

The general framework of the study described in this article is determined by the global, regional and local strategies and concepts of Education for Sustainable Development (ESD). From the Baltic Sea Region perspective, the Baltic 21E Programme (Baltic 21E, 2002) is of special importance. The aim of this programme is to enhance the role of ESD in the Baltic Sea Region so that the various dimensions of sustainable development become a natural and permanent component of educational systems. In order to fulfil the targets set by the United Nations (UN) and the Baltic 21E Programme, the Finnish Ministry of Education launched a national strategy for the UN Decade of Education for 
Sustainable Development (DESD) as the first national DESD strategy in Europe (Ministry of Education, 2006). This strategy envisages the whole educational system in Finland to act as a proactive leader in creating change for sustainability, and thus, is an innovative example of how to promote ESD at the national level. In the national strategy of Finland special emphasis is placed on the importance of research and development in cooperation with other Baltic Sea countries. The study outlined in this paper is one example that responds to this challenge from the perspective of higher education.

Promoting sustainable development, institutions of higher education can choose between two different roles. According to the first one, institutions of higher education are merely indicators of changes in attitude and knowledge within a society, and themselves cannot provide the impetus for change. The basic assumption behind this thinking is that educational institutions are created by society, and are therefore a reflection of it and are in no way a real force for social change (Wright, 2006). The other view states that institutions of higher education can and/or should be proactive leaders in promoting societal change (Giroux, 2005; UNESCO, 1997). The latter view constitutes the basic assumptions and guides the research question underlying this paper: How can higher education institutions be proactive leaders in promoting societal change?

\section{Constructive research approach}

The study is based on a constructive research approach, which can be classified as a part of the qualitative research tradition. The constructive approach has been used extensively in medicine, mathematics and technical sciences. However, the approach is used not so often in pedagogical research (Rohweder, 2008a). This research tests a suitability of constructive approach in developing ESD, and thus gives the understanding of its applicability for pedagogical research.

The starting point in the constructive research approach is a practical problem that should be solved. The goal is to develop a construct based on practical information, theoretical knowledge and heuristic development process. Therefore, the constructive approach gives new input to both theoretical argumentation and praxis (Lukka, 2000). The constructive research approach can only be chosen if researchers participating in the project have a deep understanding of the phenomenon both on the practical and theoretical level, which was the case in this study.

After determining the need for theoretical and practical development and formulating the research question, the first task in the constructive development process is to define the theoretical "framework". Tilbury and Cooke (2005) have defined the critical factors of the learning for sustainability as follows: envisioning a better future, systemic thinking, critical (reflective) thinking, participation in decision making as well as networks and partnerships for change. In addition, future orientation, value clarification, cultural thinking, participation in planning and learning, relevance and capacity building should be taken into consideration in the learning process for sustainability (Tilbury \& Ross, 2006). Similar approaches are introduced by UNESCO in the declaration of the DESD, which highlights that ESD should be interdisciplinary and holistic, values-driven and locally relevant, and should promote critical thinking and problem solving skills (UNESCO, 2004). These critical factors of learning for sustainability were chosen as the theoretical starting point for the construction process, and thus their relevance was under consideration. 
The construction phase was conducted by analyzing the practical information and the critical factors mentioned above. Practical information was gathered by organising four workshops and obtaining descriptions of eight teaching cases. The analysis of practical information was performed by the methods of text and content analysis.

The collection of practical information was initiated by setting up the model development group in the seminars organized by the Baltic University Programme (Borki Molo, Poland, March 2006) and by the Baltic Sea Sustainable Development Network (Pskov, Russia, September 2006). In Borki Molo, twenty teachers and researchers who specialized in ESD joined the project, and in Pskov an additional nine experts from the Baltic Sea Sustainable Development Network expressed their willingness to contribute to the development process. Involving teachers from the field of ESD ensured the relevance and usefulness of results for the practical work. The workshops were organized as collaborative and participatory development work where the teachers considered the theoretical foundations of the project (critical factors of ESD) in relation to their own teaching experience and expertise. In addition, the participants introduced their teaching cases, and the most innovative of them were selected as the empirical material grounding this study.

Drawing on the critical factors of ESD, the partners' descriptions of innovative teaching experiences (teaching cases) and the discussions with the partners via e-learning methods, the project managers used the content analysis method to analyze the results of the workshops and the method of text analysis for the teaching cases. Overview of cases is provided in the next section. Analysis of workshops and teaching cases permitted the authors of the article to construct the first proposal of the redeveloped critical factors of ESD.

Two other collaborative workshops were organized to further develop the critical factors of ESD presented by the project managers. A total of 22 teachers and researchers participated in the workshop, which was organized during the Baltic University Programme Conference in Lodz, Poland (May 2007). In the workshop, the project managers presented the first redeveloped version of the critical factors of ESD, and the participants collaboratively developed it further. The teams were encouraged to have a creative and critical approach. The workshop ended with presentations by the teams, which were followed by lively discussion. As a result of the workshop, the project managers made the second proposal of the critical factors for ESD. It was introduced and developed further in the workshop carried out during the Baltic Sea Sustainable Development Network Conference in Neubrandenburg, Germany (October 2007). A total of 19 teachers attended the workshop. After the project managers had presented the new version of the critical factors, five teams were formed to develop the proposal further once again. At the end, the project managers drew the final conclusions regarding the categorization and re-conceptualization of the critical factors of ESD and formulated a model of learning for sustainable development.

\section{Description of the teaching cases}

This section describes the teaching cases used as the practical information in the model construction process. The full description of cases is provided in the publication Learning for a Sustainable Future - Innovative Solutions from the Baltic Sea Region (Rohweder $\&$ Virtanen, 2008). The cases introduce eight ways to integrate sustainable development 
in higher education in Russia, Finland, Germany, Ukraine, Poland and Estonia. The cases give insights into the innovative solutions of ESD and establish the background for developing the model of learning for sustainable development.

The first case is an example from Russia. It introduces how sustainability has been integrated in education at the university in St. Petersburg. The innovative idea is to improve the educational system so that it would stimulate the creation of a new mentality of people in the $21^{\text {st }}$ century - the new generation that will be able to bring nature and humankind toward sustainable development. In addition, the case introduces the importance of networking in promotion of ESD. The case argues that wide-spread multicultural and interdisciplinary co-operation is an important part of ESD (Ionov \& Shelest, 2008).

The first case from Finland describes the basic ideas and the pedagogical background of the innovative competence-based core curriculum prepared at Laurea University of Applied Sciences as a way to integrate sustainable development into education. The curriculum renovation has encouraged a change in the whole organisational culture. Teachers need to re-orientate in their work and see students more as partners than as “objects". Sustainable development is understood as part of every individual's activities, not only as a matter of teachers who are especially devoted to it (Virtanen, 2008).

The second Finnish case is about oil combating education as a proactive way to prepare people for a potential oil spill. The case brings out an example of a study course that is based on the idea to enhance a holistic understanding of an oil spill and oil combating from the sustainable development and managerial point of view. The education is based on critical, reflective and collective learning. Open learning environments are seen as a basis for lifelong learning, and in given case the learners were both professionals and university students (Rohweder, 2008b).

In the German case different innovative teaching methods to use in education for sustainability at the university level are introduced. All the methods emphasize participation, demand that students become actively involved and contribute intellectually through problem solving. The case describes appropriate strategies and methods that will allow students to acquire the necessary competencies in problem solving and shaping social, economic, technical, and ecological transition towards a sustainable future (Grothe \& Schmeling, 2008).

The first Ukrainian case introduces two interdisciplinary courses of ESD by combining the fields of transportation, psychology and life safety. The innovative idea in the case is the creation of an intellectual transport system, the use of the matrix of the transportation flow and ecological control on the streets and how this information is transmitted to electronic big-boards through the channels of ITS communication (Zinko, Horal', Lozovyj, \& Makovejchuk, 2008).

The second Ukrainian case stresses the importance of ethics when we talk about sustainable development and attitude toward nature. The important starting point in the case is to see the world as an integrated system, and in that way, the case is an example of how systemic and holistic thinking can be implemented in education. The case also stresses the importance of partnerships and networks between the communal organisations and educational institutions (Horal', 2008). The case as such is an example of an innovative way to handle the subject of sustainable development - as an academic writing and an artistic production. 
In the Polish case study the emphasis is on the dynamics needed for the transition to sustainable development. The critical features of the case are the multi and transdisciplinary connection of many disciplines, systemic thinking and participation. The study course presented in the case integrates disciplines from ecology and economy to social studies and psychology. Simulation and systemic thinking methods help the participants to communicate, work together and integrate the complex ideas of how society and nature are changing (Krolikowska, Magnuszewski, Magnuszewska, \& Sendzimir, 2008).

A case from Estonia argues that teachers and educators have a key role in learning for sustainable development. The authors describe the sustainable development study courses that have been taught in Tallinn University to the teacher education students. Various methods are useful in ESD, such as debate, educational visits, seminars and e-learning methods (Elvisto \& Henno, 2008).

\section{Critical factors for sustainable development in higher education}

The outcome of the model development was the categorization of critical factors of ESD that describes how to enable universities to be proactive operators for sustainability in a society. In the model the critical factors of ESD are divided into context, mental and activity related aspects. Contextual factors form a framework, while mental aspects refer to intrinsic changes in the learning process for sustainability. Activities are the ways to realize educational practices for sustainability (Figure 1).

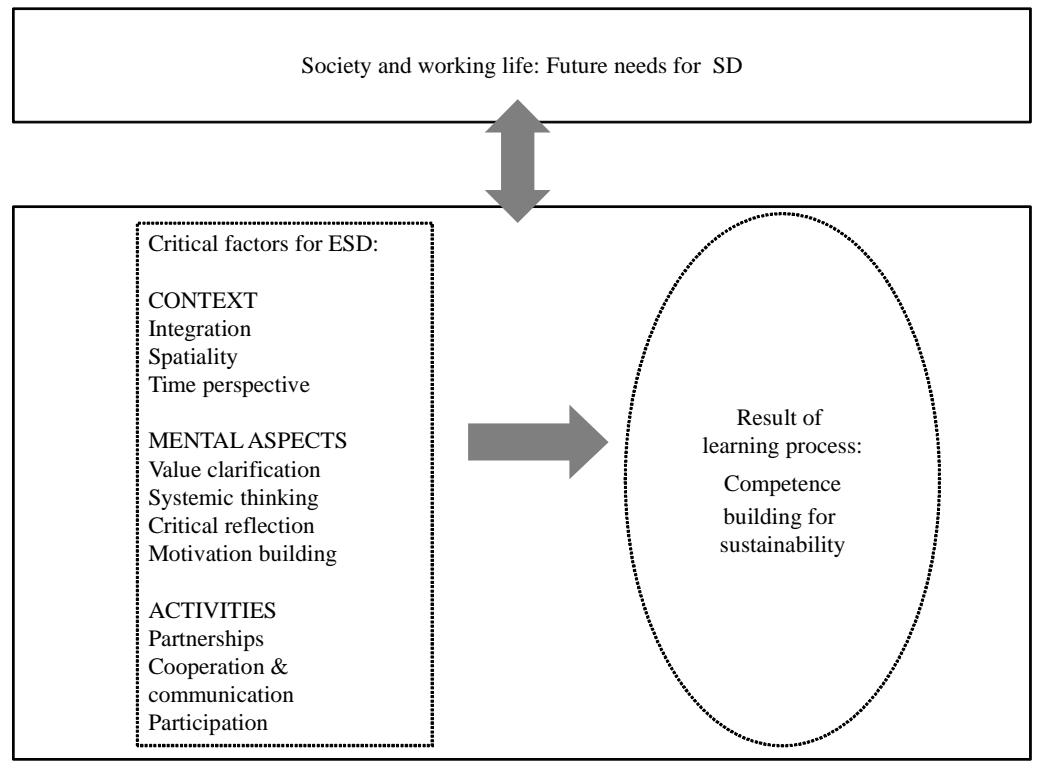

Figure 1. The model of learning for sustainable development

The Figure 1 can be briefly explained as follows: needs for ESD are based on the contemporary as well as future needs of competences to promote sustainable development 
in working life and in society at large. The critical factors for ESD are context, mental and activity related aspects. The outcome of the learning process is competence building to promote activities for sustainability. The central feature in the model of learning for sustainable development is interaction between universities and society. Adopting this kind of transformative learning circle offers possibilities for universities to be proactive actors in societal change.

Context-related critical factors for ESD are the integrative approach, spatiality and time perspective. Mental aspects are related to value clarification, systemic thinking, critical reflection and motivation building. The third category, activities, has to do with partnership, cooperation and communication as well as factors related to participation. Now we will bring a more detailed explanation of each of these factors.

An integrated and interconnected approach for sustainable development is the basis for understanding and treating the world as a harmonious entity. An integrative approach means, first of all, understanding the causal links of the dimensions of sustainable development, and handling these as interconnected and integrated with each other (Rohweder, 2007; Virtanen, 2007). Ecological questions are not separate from economic, social and cultural ones, and vice versa.

It is not easy to find something more multidisciplinary, transdisciplinary or interdisciplinary than sustainable development (Holmberg \& Samuelsson, 2006). Traditional discipline-based structure of education is not enough for education for sustainability. In order to learn about sustainable development, an understanding of several disciplines is needed. Reconnection and reconstruction of traditional educational study fields and scientific disciplines offer new possibilities for learning that emphasize a holistic and interdisciplinary approach to develop knowledge and skills as well as a necessary change in values, behaviour and lifestyles to promote sustainable development (Melén-Paaso, 2007). Wals and Corcoran (2006) use the concept of transformative learning, which requires competence building to integrate, connect, confront and reconcile multiple ways to look at the world.

In educational practices, an integrative approach becomes apparent both at the curriculum and the course level. At the curriculum level, the integrative approach means that sustainable development is not a separate course or field of study - it relates to every branch of higher education as a wider viewpoint. At the course level, the integration means to consider all dimensions of sustainability, although the focus can be on one dimension. Multidisciplinary, transdisciplinary and interdisciplinary approaches are needed for learning. For teachers in higher education, it is a challenge to understand the linkages between disciplines and to mould teaching practices towards a multidisciplinary approach and teamwork. However, this can also be a great opportunity to share knowledge, learn together and solve problems collaboratively.

Spatiality is important in the discussion of sustainable development. Learning for sustainability needs a transgeographical shift, that is, looking at sustainability issues from local to regional and global perspectives (Wals \& Corcoran, 2006). The lenses to analyse and interpret are worldwide, but at the same time the interest to manage, handle and reconstruct practices is locally oriented. In teaching situations, spatiality and time perspectives form a context as well as a perspective for learning.

The time perspective is a focal aspect in learning for sustainability. Future thinking is very significant, but without knowledge about the causal links and reasons for unsustainability it is impossible to reformulate our habits and transform the world 
towards sustainability. The determination and envisioning of qualities and criteria for the sustainable future are important in the learning process for sustainability. Having a clear vision of the sustainable future, it is possible to find tools to reach it step by step.

Envisioning should be the starting point of learning for sustainability in which people begin to feel engaged, empowered and responsible to act in ways to reach their vision for a sustainable future. The aim of envisioning is to create a positive and proactive approach to sustainability (Tilbury \& Ross, 2006). Envisioning reconstructs the values for society and environment in a new way, and in addition, it forms a motivation for activities for sustainability. For the teacher, methods such as future thinking are feasible.

Dealing with attitudes and values is seen as important in the process for sustainability (Lundholm, 2006). Discovering and reconstructing values can be seen as essential steps in the process of learning for sustainability. The question is on reflecting, articulating and arguing the reasons for unsustainable behaviour and an unsustainable world. In addition, the question is to reveal the barriers and possibilities to transform the attitudes and activities for sustainability. Revealing the values behind the everyday practices is a beginning for the journey to transform the individual habits, the workplace and society at large toward sustainability. In value clarification, people explore the links between their assumptions, biases, culture, decision making and actions (Tilbury \& Cooke, 2005). Value clarification is a useful method in teaching when exploring and reflecting on people's attitudes, opinions and values.

Systemic thinking is a way to outline the complexity of a system and the connectivity of its parts. Systemic thinking offers a way to understand and manage complex processes as it emphasizes a holistic and integrative approach. Concepts such as combined thinking, integrative thinking, relational thinking and holism are used to refer to systemic thinking (Tilbury \& Cooke, 2005). Systemic thinking leads to re-evaluation and reconstruction of a fragmentary and reductionist worldview, which traditionally underpins the curriculum in educational institutions. Systemic thinking challenges us to formulate higher education according to the principles of interconnectedness, holism, and an interdisciplinarity and cross-curricular approach. Teamwork and collaboration between disciplines offer possibilities to see beyond separate disciplines, to combine knowledge and define new multidiscipline concepts and solutions for sustainability.

Critical and reflective thinking helps to construct the individual and group capacity for learning for sustainability. For instance, UNESCO (2002) has declared critical reflection to be an important element of ESD:

Education for sustainable development must explore the economic, political and social implications of sustainability by encouraging learners to reflect critically on their own areas of the world, to identify non-viable elements in their own lives and to explore the tension among conflicting aims (p. 11).

Critical and reflective thinking challenges us to find a new interpretation for our activities, workplaces and the whole world. Reflection can be viewed as a critical self-evaluation of our work, thinking and everyday practices. Critical reflection also means discussions and open dialogues with colleagues. A critical viewpoint encourages us to reconstruct our understanding of the world and its political, economic and social structure (Tilbury \& Cooke, 2005). Critical reflection on its highest level demands students, teachers and other stakeholders to question their preconceptions of issues and create new or modified interpretations to understand and realize activities for sustainability. 
At an individual level learning for sustainability means to build motivation, knowledge and skills. Motivation, knowledge and skills are intertwined; motivation is an inspirer for the search of knowledge and mastering of skills to act for sustainability. A teacher's role is to build the motivation towards sustainable practices, to transfer knowledge of sustainability, and to teach how to act and behave in terms of sustainable development.

The sustainability also requires new kinds of partnerships. Ideally, partnerships for sustainability are based on a collaborative culture. Such partnerships can be established between the educational communities, public organisations, non-governmental organisations, local communities, entrepreneurs, etc. By bringing together different groups from different sectors with diverse knowledge and skills, partnerships can build collective knowledge through social learning. In addition, for learning for sustainability an effective and open-minded participation of all stakeholders is necessary. In order to be successful, partnerships require trust, open dialogue and communication, defined and accepted roles as well as transparency and accountability with attention to the issues of equity and fairness (Tilbury \& Ross, 2006).

Cooperation and communication between institutions of higher education is important, but to fulfil their service functions for the workplace and society, cooperation with external stakeholders is required. Institutions of higher education will have to be centred in international, national and regional networks as well as in networks with other partners, such as primary and secondary schools, vocational education, science centres, companies, NGOs, national and regional governments, etc. (Dam-Mieras, 2006). Cooperation and communication assure a proactive nature for education. When education reflects and corresponds to the workplace and society's needs, it has a powerful capacity to produce competencies for the future needs.

Participation requires involvement on different levels starting from the consultation and consensus building to decision making, risk sharing and collective partnerships. In ESD, participation is connected to decision making for sustainability and to wide participation of students and other stakeholders in the learning process. Through participation people can build knowledge and skills as well as take responsibility for outcomes. Participation occurs through active involvement and dialogic discussions. Participation in the learning process for sustainability is an important instrument to recognise the value and relevance of local and context-specific issues (Tilbury \& Cooke, 2005). By using various learning tasks that involve teamwork, the participatory character of teaching can be strengthened.

Competence building for sustainability is a result of the learning process and development at individual, organisation/community and institutional/societal levels. At the individual level, competence building equips individuals with the motivation, understanding, skills and access to information, knowledge and training, which enables them to perform according to the principles of sustainable development. Learning and development at the organisation or community level form the management structures and processes, and everyday activities for sustainable development. Competence building at institutional level introduces the changes for sustainability in legal and regulatory systems as well as in other social structures. 


\section{Challenges for higher education and reflections on the development process}

The model of learning for sustainable development introduced in this article proposes not only new challenges, but also new possibilities for teachers in institutions of higher education to enhance the quality of their teaching. The model offers a framework to reorient teaching not only by content, but also by methods. As learning for sustainability is not only transference of knowledge, reorientation of values and habits, creation of experiential learning situations and critical reflection are needed. Teaching and learning in multidisciplinary teams offers the possibility to see beyond the limits of traditional disciplines and to find new solutions to combine knowledge from different disciplines thus promoting holistic and systemic thinking. In addition, working in multidisciplinary teams (consisting of work life representatives, teachers and students) means that the teacher's traditional role as a mediator of knowledge starts to change. In this kind of praxis-based teaching the teacher is a facilitator, mentor, developer and a colleague not only in the university context, but also in a wider social context. The important target is to promote a transformative learning circle, in which not only students but also teachers and work life representatives learn together by solving problems and developing new innovations for sustainability.

The constructive approach used in the development of the model was a challenge since only a few theoretical references about its suitability for pedagogical research are available. However, according to our understanding the opportunities it offers for pedagogical research have not been revealed fully yet. We argue that the constructive approach is highly relevant in the research tradition of applied sciences, which ESD evidently represents. From a constructive point of view the research and development process was successful because it shows an example of collective and participative learning, critical reflection and collaborative competence building. The biggest challenge of using the approach is connected with reliability and validity related aspects. The validity and reliability of the study was established by describing the whole development process of model in detail. Thus the reader can follow how the forming of the project group, collection and analysis of research data as well as the rest of the construction process was performed.

The final result of this project is not an end in itself or the only acceptable solution to the wide and complex question of how to define the critical factors of education for sustainability. Hopefully, the model and the critical factors presented in this paper will stimulate further discussion on how to teach sustainable development and how to enhance the learning process for sustainability. As there is no universal definition of sustainable development, there can be no universal model of how to promote sustainable development in higher education. On the other hand, it is of upmost importance to open our eyes to multiple solutions in this regard.

\section{References:}

Baltic 21E. (2002). An Agenda 21 for Education in the Baltic Sea Region-Baltic 21E. Retrieved February 14, 2009, from http://www.baltic21.org/attachments/ no22002 education_sector_report.pdf

Dam-Mieras van, R. (2006). Learning for sustainable development: Is it possible within the established higher education structures? In J. Holmberg \& B. E. Samuelsson 
(Eds.), Drivers and barriers for implementing sustainable development in higher education (pp. 13-18). Education for Sustainable Development in Action, Technical Paper 3, UNESCO.

Elvisto, T., \& Henno, I. (2008). Sustainable development in teacher education in Estonia. In L. Rohweder \& A. Virtanen (Eds.), Learning for a sustainable future. Innovative solutions from the Baltic Sea Region (pp. 123-129). Uppsala: The Baltic University Press.

Giroux, H. (2005). Against the new authoritarianism. Winnipeg: Arbeiter Ring Publishing.

Grothe, A., \& Schmeling, M. (2008). Methods to teach sustainability in a business school in Germany. In L. Rohweder \& A. Virtanen (Eds.), Learning for a sustainable future. Innovative solutions from the Baltic Sea Region (pp. 85-97). Uppsala: The Baltic University Press.

Holmberg, J., \& Samuelsson, B. E. (2006). Executive summary. In J. Holmberg \& B. E. Samuelsson (Eds.), Drivers and barriers for implementing sustainable development in higher education (pp. 7-11). Education for Sustainable Development in Action, Technical Paper 3, UNESCO.

Horal', N. (2008). Ukrainian view of ethics on the way to sustainable development. In L. Rohweder \& A. Virtanen (Eds.), Learning for a sustainable future. Innovative solutions from the Baltic Sea Region (pp. 117-111). Uppsala: The Baltic University Press.

Ionov, V., \& Shelest, K. (2008). Experience on sustainable development in higher education in St.-Petersburg in Russia. In L. Rohweder \& A. Virtanen (Eds.), Learning for a sustainable future. Innovative solutions from the Baltic Sea Region (pp. 6775). Uppsala: The Baltic University Press.

Królikowska, K., Magnuszewski, P., Magnuszewska, J., \& Sendzimir, J. (2008). Dynamics of sustainable development - Karkonosze Mountains and Odra River Valley in Poland. In L. Rohweder \& A. Virtanen (Eds.), Learning for a sustainable future. Innovative solutions from the Baltic Sea Region (pp. 112-122). Uppsala: The Baltic University Press.

Lukka, K. (2000). The key issues of applying the constructive approach to field research. In T. Reponen (Ed.), Management expertise for the new millennium (pp. 113128). In commemoration of the $50^{\text {th }}$ anniversary of the Turku School of Economic and Business Administration (Series A-1).

Lundholm, C. (2006). The challenges facing learners in EE and ESD. In J. Holmberg \& B. E. Samuelsson (Eds.), Drivers and barriers for implementing sustainable development in higher education (pp. 55-58). Education for Sustainable Development in Action, Technical Paper 3, UNESCO.

Melén-Paaso, M. (2007). The paradigm of sustainable development and education Reflections on the past and on the future. In T. Kaivola \& L. Rohweder (Eds.), Towards sustainable development in higher education - Reflections (pp. 110-114). Helsinki: Helsinki University Press (Publications of the Ministry of Education 2007: 6).

Ministry of Education. (2006). Sustainable development in education; Implementing of Baltic 21E Programme and Finnish strategy for the Decade of Education for Sustainable Development (2005-2014). Reports of the Ministry of Education 2006: 6 . 
Rohweder, L. (2007). What kind of sustainable development do we talk about? In T. Kaivola \& L. Rohweder (Eds.), Towards sustainable development in higher education - Reflections (pp. 22-26). Helsinki: Helsinki University Press (Publications of the Ministry of Education 2007: 6).

Rohweder, L. (2008a). Konstruktiivinen tutkimusote pedagogiikan kehittämisessä [Constructive research approach in pedagogical development]. In L. Rohweder \& A. Virtanen (Eds.), Kohti kestävää kehitystä-pedagoginen lähestymistapa [Towards sustainable development - pedagogical approach] (pp. 11-16). Helsinki: Helsinki University Press (Publications of the Ministry of Education 2008: 3).

Rohweder, L. (2008b). Preparing for an oil spill through oil combating education in Finland. In L. Rohweder \& A. Virtanen (Eds.), Learning for a sustainable future. Innovative solutions from the Baltic Sea Region (pp. 130-138). Uppsala: The Baltic University Press.

Rohweder, L., \& Virtanen, A. (Eds.). (2008). Learning for a sustainable future. Innovative solutions from the Baltic Sea Region. Uppsala: The Baltic University Press.

Tilbury, D., \& Cooke, K. (2005). A national review of environmental education and its contribution to sustainability in Australia: Frameworks for sustainability. Canberra: Australian Government Department of the Environment and Heritage and Australian Research Institute in Education for Sustainability.

Tilbury, D., \& Ross, K. (2006). Living change: Documenting good practice in education for sustainability in NSW. NSW: Madquarie University, Sydney \& Nature Conservation Council.

UNESCO. (1997). Thessaloniki Declaration. Gland: United Nations Educational, Scientific and Cultural Organization.

UNESCO. (2002). Education for sustainability: From Rio to Johannesburg: Lessons learnt from a decade of commitment. Paris: United Nations Educational, Scientific and Cultural Organization.

UNESCO. (2004). United Nations Decade of Education for Sustainable Development 2005-2014. Draft International Implementation Scheme. Retrieved February 14, 2009, from http://portal.unesco.org/education/en/ev.php-URL ID=27234\& URL DO=DO TOPIC\&URL SECTION=201.html

Virtanen, A. (2007). Sustainable development in natural resources and environment studies. In T. Kaivola \& L. Rohweder (Eds.), Towards sustainable development in higher education - Reflections (pp. 86-95). Helsinki: Helsinki University Press (Publications of the Ministry of Education 2007: 6).

Virtanen, A. (2008). Curriculum reformation for sustainable development in Finland. In L. Rohweder \& A. Virtanen (Eds.), Learning for a sustainable future. Innovative solutions from the Baltic Sea Region (pp. 76-84). Uppsala: The Baltic University Press.

Wals, E. J., \& Corcoran, P. B. (2006). Sustainability as an outcome of transformative learning. In J. Holmberg \& B. E. Samuelsson (Eds.), Drivers and barriers for implementing sustainable development in higher education (pp. 103-110). Education for Sustainable Development in Action, Technical Paper 3, UNESCO.

Wright, T. S. A. (2006). The role of research in achieving sustainable future? In J. Holmberg \& B. E. Samuelsson (Eds.), Drivers and barriers for implementing sustainable development in higher education (pp. 121-125). Education for Sustainable Development in Action, Technical Paper 3, UNESCO. 
Zinko, R., Horal', N., Lozovyj, I., \& Makovejchuk, O. (2008). The role of interdisciplinary courses in gaining sustainable education in Ukraine. In L. Rohweder \& A. Virtanen (Eds.), Learning for a sustainable future. Innovative solutions from the Baltic Sea Region (pp. 98-106). Uppsala: The Baltic University Press.

\section{Correspondence:}

Liisa Rohweder, PhD, Haaga-Helia University of Applied Sciences, Ratapihantie 13, 00520 Helsinki, Finland. Email: liisa.rohweder@haaga-helia.fi

Received 13 February, 2009; revised version received 22 April, 2009 